8-21-2015

\title{
The Good Behavior Game for Latino English Language Learners in a Small Group Setting
}

Jennifer Ortiz

University of Connecticut - Storrs, jenmortiz@gmail.com

Follow this and additional works at: https://opencommons.uconn.edu/dissertations

\section{Recommended Citation}

Ortiz, Jennifer, "The Good Behavior Game for Latino English Language Learners in a Small Group Setting" (2015). Doctoral Dissertations. 885.

https://opencommons.uconn.edu/dissertations/885 
The Good Behavior Game for English Language Learners in a Small Group Setting Jennifer Ortiz, Ph.D.

University of Connecticut, 2015

The Good Behavior Game (GBG) is a group contingency intervention that has effectively reduced disruptive behavior and improved classroom management in many replications, for various settings and populations. The student composition of American public schools is changing, leading to culturally and linguistically diverse classrooms with unique psychoeducational needs. The present study used a single-subject, delayed multiple baseline design to evaluate the GBG as a targeted intervention for third grade Latino English Language Learners (L-ELLs) who participated in a small group for behavior support. Results suggest the intervention had a moderate effect on the interrupting behavior of the target students. The results provide further support for the use of the GBG with culturally and linguistically diverse students, and suggests the potentially positive impact of the GBG on the outcome of the individual student in a small group setting. Considerations for conducting research with culturally and linguistically diverse populations are discussed. 
The Good Behavior Game for English Language Learners in a Small Group Setting

\author{
Jennifer Ortiz
}

B.A., University of Connecticut, 2007

M.A., University of Connecticut, 2009

\author{
A Dissertation \\ Submitted in Partial Fulfillment of the \\ Requirements for the Degree of \\ Doctor of Philosophy \\ at the \\ University of Connecticut \\ 2015
}


Copyright by

Jennifer Ortiz

2015

ii 


\section{APPROVAL PAGE}

\section{Doctor of Philosophy Dissertation}

The Good Behavior Game for Latino English Language Learners in a Small Group Setting

Presented by

Jennifer Ortiz, B.A., M.A.

Major Advisor:

Melissa A. Bray, Ph.D.

Associate Advisor:

Thomas Kehle, Ph.D.

Associate Advisor:

Eliana D. Rojas, Ph.D.

University of Connecticut

2015 


\section{ACKNOWLEDGEMENTS}

I would like to thank my school site for both my gainful employment and also for granting me permission to conduct this study. I want to thank Dr. Candace Ward-McKinlay and Alejandro Ortiz for their approval and support, Dr. Joanne Leon, for her continued encouragement as well as guidance in every aspect of the job, and my students and teachers for their participation and daily contribution to my education.

I would like to thank my advisor, Dr. Melissa Bray, who gave me the perfect combination of patience, time, and encouragement I needed to complete this, and my advisory committee, for their input, ideas, and support during the long years of this process. I am forever indebted to my cohort, who helped me hurdle many roadblocks (and who were in general an awesome group of people to spend three years with) and specifically Rose Jaffery, who was indispensable in the completion of this document. I also want to thank my parents, my siblings, my love, and my biffles, who pushed me to finish when I lost sight of the purpose, and for feigning interest in hearing about my project again. I promise, I will never give you a copy. 


\section{TABLE OF CONTENTS}

Approval Page_ iii

Acknowledgments _ iv

Table of Contents $\quad$ v

List of Tables vii

List of Figures __vii

List of Appendices_ ix

CHAPTER I: LITERATURE REVIEW _ 1

English Language Learners and Behavior 1

The Good Behavior Game 3

Summary and Rationale $\quad 14$

Research Questions 16

CHAPTER II: METHODS 17

Participants and Setting _ 17

Procedure 18

Materials 18

Design__ 19

Procedures 20

Treatment Fidelity 21

Outcome Measures 22

Dependent Variables _ 22

Observation Procedures $\quad 22$

Data Analysis_ 23

CHAPTER III: RESULTS 24

Attrition 24

Reduction of Disruptive Behaviors 25

Interrupting 25

Out of Seat Behavior 227

Treatment Fidelity__ 28

CHAPTER IV: DISCUSSION $\quad 30$

Effects of the Good Behavior Game on Behavior 31

Implications 33

Limitations $\quad 34$

Future Research 37

Summary_ 38 
REFERENCES

TABLES

FIGURES 52

APPENDICES

54 


\section{LIST OF TABLES}

TABLE 1. Effect Size Calculations for Interrupting Behavior 50

TABLE 2. Effect Size Calculations for Out-of-Seat Behavior 


\section{LIST OF FIGURES}

FIGURE 1. Frequency of Interrupting Behavior per Session

FIGURE 2. Frequency of Out-of-Seat behavior per Session 


\section{LIST OF APPENDICES}

APPENDIX A. Parent Permission Form, English $\quad 55$

APPENDIX B. $\quad$ Parent Permission Form, Spanish_ 58

$\begin{array}{lll}\text { APPENDIX C. } & \text { Assent Script } & 62\end{array}$

APPENDIX D. Baseline Implementation Checklist and Data Collection Form__ 64

APPENDIX E. Intervention Implementation Checklist and Data Collection Form_66 


\section{CHAPTER I}

\section{LITERATURE REVIEW}

Researchers estimate that at least one in five American students has experienced a mental health problem in the past six months, but only $16 \%$ of these students will have access to treatment (Burns et al, 1995; Rones \& Hoagwood, 2000). Of those that do receive treatment, as many as $80 \%$ will receive services within school settings. In recent years, the responsibility of school systems to provide better care and services has increased, thus increasing the need for evidence-based interventions (Walker, 2004). As researchers continue to emphasize the need for practices informed by empirical research, we must make certain that the samples on which interventions are assessed are representative of the diverse students who will be receiving them. The faces of the American public school system are changing. In 2000, 17\% of American primary and secondary students were Latino. By 2007, Latinos comprised $21 \%$ of the school population. Twenty one percent of American students speak a language other than English at home, and 5\% of students have difficulty speaking English. While demographics vary largely by region, classrooms are becoming increasingly culturally and linguistically diverse, presenting new needs to be met by school-based services.

\section{ENGLISH LANGUAGE LEARNERS AND BEHAVIOR}

Few researchers have documented the unique background and experiences that Latinos and Latino English Language Learners (L-ELLs) have before entering American schools. Studies of cultural differences demonstrate the variance in customs and family across cultures and levels of acculturation (Tapia, 2004). Latinos are more likely to have 
diverse household structures, and to share and pool resources with extended family and community members. These community contexts impact students' academic behaviors and achievement. A study of classroom social behavior compared the cooperative work of students who were Mexican immigrants and students of European descent (MejíaArauz, Rogoff, Dexter \& Najafi, 2007). Mexican students were more likely to choose to work as a group to complete a task, while their white peers were more likely to work independently or in pairs.

Latinos and L-ELLs are at higher risk for a number of negative academic outcomes. Twelve percent of Latinos have been retained at least once, and $20 \%$ have been suspended (Aud, Fox \& KewalRamani, 2010). Among Latinos ages 16-24, $21 \%$ of young adults have dropped out of school. While this is the lowest dropout rate in over 10 years, this number has exceeded the dropout rate of every other racial group for the past decade. As indicated above, there is a small field of evidence about the behavioral differences observed in L-ELLs, and the connection of these behaviors to cultural differences rather than deviance or maladjustment. However, educators have the responsibility of helping all students to learn appropriate school behaviors. To address this need, researchers and educators should consider behavior interventions that would target both social, emotional, and behavioral needs, as well as cultural roots of behavior differences, while reinforcing positive, expected behavior. A review of school psychology research published from 2004-2010 found that $15.5 \%$ of articles addressed racial, cultural, linguistic, sexual orientation, or socioeconomic diversity (Grunewald, et al., 2014). Of these 222 published reports, $15.3 \%$ addressed prevention or intervention for academic, behavioral, or social-emotional needs. This amounts to just 34 articles 
published over six years that consider supports for any diverse group of students, including cultural groups, religions, sexual orientations, ELLs, or different socioeconomic statuses. The present research aims to identify and evaluate a researchbased classroom intervention that is likely to be effective with behavior issues stemming from both social-emotional functioning as well as cultural differences.

\section{GOOD BEHAVIOR GAME}

The Good Behavior Game (GBG) is a classroom management intervention designed to reduce off-task and disruptive behaviors through a "game" that incorporates competition, group contingency, and positive reinforcement (Barrish, Saunders \& Wolf, 1969). The game utilizes a classroom management model of behavior modification (Embry \& Straatemeier, 2001). Rather than focusing on the identification and treatment of the underlying cause of a problem behavior, the program applies theory-based training and reinforcement to promote a change in the observable behavior. The goal of the GBG is to decrease the frequency of off-task and disruptive behaviors and consequently increase on-task and appropriate behaviors during instruction. Targeted behaviors may include leaving one's seat without permission, calling out, noncompliance or aggression. Selected behaviors are monitored during the same predetermined instructional period each day. The class or sample can be split into teams, which adds an element of competition between groups to the game. The team that exhibits the fewest disruptive behaviors at the end of the session is eligible for a reward. Alternatively, the implementer can designate a "threshold" or criterion, and if the class (or a team within the class) keeps their number of disruptive behaviors beneath the threshold, then they are 
eligible for reinforcement. This class-wide intervention is most often used as a preventative intervention or a Tier I or universal strategy to promote on-task behavior at the level of the whole class, but select research suggests efficacy at the individual level as well (Upson \& Skinner, 2002).

The GBG incorporates many components that may make the program a good fit for L-ELLs. The program employs a group contingency format of reinforcement, meaning that the reinforcer is earned by the group contingent upon the behavior of all members of the group (Cooper, Heron \& Heward, 2007). Group contingency interventions have been found to effectively reduce problem behavior (Maggin, Johnson, Chafouleas, Ruberto \& Berggren, 2012). The outcome for one student is the same as the outcome for their entire team or group, and the choices or actions of one may affect the entire group. This model may fit well with L-ELLs' cooperative behavior as reported by Mejía-Arauz and colleagues (2007). Additionally, the language demands of the program are minor, and the loss of instructional time is minimal, meaning the intervention may also be appropriate for students with language proficiency or academic needs. Finally, the GBG has been implemented and evaluated extensively over the past 45 years, and while new replications have been conducted with diverse populations or international settings (Nolan, Houlihan, Wanzek \& Jenson, 2014) further research is still needed to develop the GBG's efficacy with Latinos or ELLs in the U.S.

A commercial version of the game is available through the Paxis Institute and the Hazelden Foundation. The packaged program comes with guides for interventionists and parents, a timer, stickers and wristbands. The publishers also have developed a school wide implementation guide, school-to-home postcards, an instructional DVD, and 
supplemental materials in Spanish for parents (Embry, 2004). The manual states that one game can be purchased for school-wide use, making the cost-per-student extremely reasonable.

\section{Development and Evaluation}

The GBG was first developed and assessed with a fourth-grade class that lacked whole-classroom management and also included students with high numbers of office discipline referrals (Barrish, Saunders, \& Wolf, 1969). The teacher split the class into two teams, and presented operationally defined expectations for calling out behavior and out-of-seat behavior. Talking-out behavior decreased by $77 \%$, and out-of-seat behavior decreased by $73 \%$ during treatment phases, although recovery was observed during the return to baseline. The program was then implemented in a second instructional block in the same classroom. The intervention was replicated with a fifth grade class, in which behaviors decreased by $99 \%$, and showed a maintenance effect during the return to baseline (Medland \& Stachnik, 1972). The researchers suggested that the positive behavior became reinforced by circumstances outside of the intervention, and although this demonstrates generalizability of the effect, it limits experimental control. Harris and Sherman (1973) conducted an analysis of components to see which most impacted the GBG's efficacy. The authors found that while the method of providing direct teacher feedback or acknowledgement of behavior had little influence on the overall success, the criterion level, the specific reinforcer offered, and the use of teams all had a significant impact on the efficacy of the program. A systematic review of 45 A-B contrasts in 22 articles found that $87 \%$ of published, reviewed evaluations yielded moderate to large effect sizes (Flower, McKenna, Bunuan, Muething \& 
Vega (2014). The review also found that clear, operationally defined target behaviors and the use of rewards are associated with greater effects.

Because of its success in many replications, the GBG is often considered a "best practice" in school-based interventions and classroom management (Conroy, Sutherland, Snyder \& Marsh, 2008). Conroy and colleagues stated that the GBG can help increase students' positive (and decrease negative) behaviors, as well as improve teachers' discipline and rule-setting skills. Embry (2002) described the intervention as a "behavioral vaccine" against violence, substance use, and antisocial behaviors. The American Federation of Teachers (2000) considered the GBG a promising program for violence prevention. A survey of educators indicated teachers find the GBG acceptable for use with all grade levels (Tingstrom, 1994). However, some disadvantages have been identified, such as the opportunity for one or few students to sabotage the game, or negative response from peers for those that hurt their team's performance (Tingstrom, Sterling-Turner \& Wilczynski, 2006).

\section{Long Term Outcomes}

A research team from Johns Hopkins University conducted a series of longitudinal studies of the outcomes associated with the GBG in early childhood. Classrooms in 19 diverse public schools in the Baltimore, MD received the GBG through first and second grade, and were assessed on a variety of outcomes at several ages (Kellam, Ling, Merisca, Brown, \& Ialongo, 1998). Results showed that classroom aggression in first grade significantly increased the risk of individual aggression in grade six for males, but receiving the GBG in first grade reduced this effect. Smoking initiation was assessed at age 14 for students who received the GBG versus the control condition 
(Kellam \& Anthony, 1998). For male participants in the GBG classrooms, initiation was significantly lower.

A series of follow-up studies were conducted when participants reached 19-21 years of age. Kellam and colleagues found that the GBG was associated with greater likelihood of a range of positive outcomes, including lower alcohol and substance use or dependence, reduced smoking, lowered incidence of Antisocial Personality Disorder (ASPD) and improved graduation rate (Kellam et al., 2008), as well as reduced engagement in high-risk sexual behaviors and lowered incidence of drug dependence disorders (Kellam et al., 2014) and reduced suicide ideation and attempt by age 19-21 (Wilcox et al., 2008). Another trial found that when compared to a family-school partnership or control group, students who received the GBG throughout grade 1 had significantly higher college attendance rates and reduced likelihood of special education placement than both groups (Bradshaw, Zmuda, Kellam \& Ialongo, 2009).

The researchers also conducted replications where behaviors or risks were identified a priori to monitor development of select characteristics or outcomes over time. Students who were identified as aggressive or disruptive in first grade, and who then received the GBG, later self-reported a reduced use of school-based services for emotional, behavioral, or substance use problems when assessed at ages 19-21 (Poduska et al., 2008). Additionally, incidence of violent or criminal behavior and ASPD was significantly lower for male participants determined to be at persistent high risk for aggressive or disruptive behavior (Petras et al., 2008).

\section{Variations}


Since its development, the GBG has been replicated with success in students as young as preschool and kindergarten (e.g. Swiezy, Matson \& Box, 1992; Donaldson, Vollmer, Krous, Downs \& Berard, 2011; McGoey, Schneider, Rezzetano, Prodan \& Tankersley, 2010) and up to high school (e.g. Flower, McKenna, Muething, Bryant \& Bryant, 2014; Kleinman \& Saigh, 2011). The GBG has also served as a platform for analysis of intervention implementation and assessment, such as treatment integrity (e.g. Sanetti \& Kratochwill, 2011) and coaching (Becker, Bradshaw, Domitrovich, \& Ialongo, 2013). Researchers have expanded or modified Barrish's original procedures to accommodate new target behaviors, settings beyond the classroom, and varying intervention goals.

In a study by Upson and Skinner (2002), a regular education teacher requested targeted support for three students exhibiting problem behaviors in the classroom. Instead of providing supports for those students in isolation, the GBG was implemented for the entire class, and progress was monitored at the level of the classroom and the individual target students. The game resulted in reduced disruptive behaviors and increased on-task behaviors for the target students, as well as overall improvement for the entire class. The trend indicates a functional relationship between the intervention and improvement at the individual level. This study demonstrated to the consultee the utility of the GBG at multiple tiers of intervention. At the whole class level, there is a positive effect as prevention and a universal intervention (Tier I within the Response-toIntervention model; Gresham, 2004). At the level of the individual, with students who are identified as having greater behavioral needs, there is an effect as a targeted support within the classroom (Tier II). 
In a Chicago after-school program, the GBG was introduced as a part of a comprehensive program redesign (Frazier, Chacko, Van Gessel, O'Boyle \& Pelham, 2012). The GBG was utilized to provide a convenient way to monitor students' behavior each session without the intensity of using individual behavior reports. While quantitative analyses were not available, the researchers reported that the GBG was well received by the program, which services urban youth in the city's south side, and provided an easy and effective method of monitoring students' daily behavior.

Another adaptation involved the use of the GBG in an urban school cafeteria with diverse students (McCurdy, Lannie \& Barnabas, 2009). Lunch aides served as the implementers of the intervention in three lunch waves using a multiple baseline design. The researchers saw an immediate, noticeable reduction in behaviors. Results indicated a significant change in level in all three lunch waves, and a change in trend for two waves.

Dion and colleagues (2011) investigated the potential impact of the GBG on academic interventions. The team enrolled 58 first-grade classrooms in Montreal's poorest areas to control or reading intervention conditions. Select classrooms received the GBG in addition to reading support; while the GBG was not associated with greater reading improvement compared to the academic intervention alone, it did improve student's attention during the GBG sessions.

As schools move toward a focus on positive behavior and supports, variations of the GBG that promote teacher recognition of positive behaviors have been developed. Robertshaw and Hiebert (1973) present likely the first positive variation of the GBG, called the Astronaut Game, during which first graders earned tokens for "good astronaut behavior" such as task completion. The game led to improved work completion and on- 
task behavior. In another trial, teachers alternated between the traditional GBG procedure and a variation that incorporated acknowledgement of positive behavior (Tanol, Johnson, McComas \& Cote, 2010). While both intervention methods were equally effective and rated equally acceptable as a behavior management strategy, teachers reported personal preference for the positive variation. Another replication proposed the "Caught Being Good Game" which also emphasized feedback for positive behaviors (Wright \& McCurdy, 2012). Two elementary classes with the same teacher were enrolled; one class was exposed to the traditional program, and one to the Caught Being Good Game. Both classes demonstrated similar improvement in behavior, suggesting that adjusting the GBG to emphasize positive behavior is similarly effective.

\section{Diverse Populations}

The GBG is unique in its extensive successful replication, as well as emerging application with diverse and even international populations (Nolan et al., 2014). One of the earliest international studies assessed the GBG with fourth graders in summer school in Germany (Huber, 1979). The game reduced aggressive behavior, talking back, and outof-seat behavior. Early replications saw similar efficacy with intermediate grades in the UK (Phillips \& Christie, 1986) and British Columbia (Kosiec, Czernicki \& McLaughlin, 1986).

Within American schools, research samples have expanded to include urban school settings, a range of socioeconomic levels, and culturally diverse samples. For example, Kellam and colleagues' large, longitudinal studies in Baltimore included many urban schools and schools with primarily African American populations (e.g. Kellam et al., 1998). Lannie and McCurdy (2007) replicated the GBG with first graders in an urban 
area where $80 \%$ of students receive free or reduced lunch. The researchers predicted that the game would decrease off-task and disruptive behaviors, as well as increase the frequency of teachers' praise statements. While the GBG led to a decrease in target behaviors, no change was observed in teacher praise, which the researchers suggest may be due to a need for explicit training to utilize praise statements. In diverse classrooms comprised of ELLs, students with academic and behavioral problems, and even giftedness, a positive variation of the GBG was implemented to increase compliance, discipline and work completion. Teachers provided feedback for positive behavior only, and students monitored and reported their own behavior (Babyak, Luze \& Kamp, 2000). Teachers saw a significant improvement in remaining on-task and staying in one's seat in each classroom, and they agreed the intervention was beneficial. In addition, $91 \%$ of students enjoyed playing the game, $94 \%$ reported the game helped them complete their work, and $100 \%$ enjoyed earning rewards.

The GBG was implemented in first-grade classrooms in schools in the Netherlands (van Lier, Muthén, van der Sar \& Crijnen, 2004). Students were classified as being on a high, medium, or low trajectory for attention deficit/hyperactivity problems, oppositional defiant problems, and conduct problems. Behavior outcomes were assessed at several data points using Achenbach rating scales and structured teacher interviews. The GBG was associated with improved ratings related to conduct problems for hightrajectory students, and reduced all three problems for medium-trajectory students. Long-term follow up with this sample found that participants experienced reduced antisocial behaviors and peer rejection (van Lier, Vuijk, \& Crijnen, 2005) and early onset smoking (Huizink, van Lier \& Crijnen, 2009). 
Further studies of kindergarten children in the Netherlands found that the GBG was associated with improved peer relations and decreased internalizing symptoms and externalizing behaviors (Witvliet, van Lier, Cuijpers \& Koot, 2009; Vuijk, van Lier, Crijnen \& Huizink, 2007). Spilt, Koot and van Lier (2013) attempted to identify subgroups of this kindergarten sample who were most likely to benefit from implementation of the GBG as a universal prevention tool. Teachers completed behavior checklists and interviews to assess risk factors and identify subgroups at baseline, and to measure progress post intervention. The researchers found that the GBG was significantly more effective at reducing internalizing and externalizing behaviors of students who were identified at baseline as having higher risk for internalizing behaviors, victimization from peers, and overall low risk. Significantly lower effects were observed for students with moderate or severe behavior problems and students with family or home issues such as low parental involvement, family stress, or poverty.

In Belgium, the GBG was implemented as a prevention program for second grade students, and was continued through their third grade year (Leflot, van Lier, Onghena \& Colpin, 2010). Compared to the students in control classrooms, those who received the GBG showed a reduced development of hyperactive and oppositional behavior.

In a school in rural Andalusia, Spain, a variation of the GBG included the SayDo-Report Correspondence (Ruiz-Olivares, Pino \& Herruzo, 2010). At the start of each session, the teacher guided the students to "say" what they will do (or not do in terms of disruptive behavior), then to "do" that for the duration of the game, and finally to "report" if they followed through at the end of each session. The results indicate this 
variation effectively reduced disruptive behaviors, consistent with the standard GBG procedure. Additionally, the researchers observed a maintenance effect.

In rural Sudan, the GBG was assessed in a second-grade classroom (Saigh \& Umar, 1983) in a study that demonstrated high experimental control. During treatment phases, there was a significant decrease in aggression, talking out, and out-of-seat behavior. The authors suggest that this evaluation establishes "cross-cultural utility" for the GBG (Saigh \& Umar, p.343).

Application of the GBG in Latin American regions is slowly emerging. Four first grade classrooms in public schools in Chile received the intervention for the first half of the academic year (Pérez, Fernández, Rodríguez \& De la Barra, 2005). The intervention classrooms, and a control group, had similar scores on a psychosocial risk index. The results indicated that exposure to the GBG was associated with reduced rates of outcomes such as aggression, hyperactivity, and inattention at follow-up relative to the control group. The GBG was introduced into three elementary classrooms in Belize, where the school population included students of Mestizo, Kriol, Spanish, North American, and Mayan ethnicities (Nolan, Filter \& Houlihan, 2014). The intervention was evaluated following the adoption of the Education and Training Act to end corporal punishment in schools, which has led to a great need for evidence-based behavioral practices in schools. The intervention was effective, leading to a reduction in frequency of each target behavior.

\section{SUMMARY AND RATIONALE}


Immigration from Latin American countries continues to increase, and schools are facing larger ELL and bilingual populations than ever. These students face the unique challenge of both linguistic and cultural diversity. Those with previous school experience must rapidly transition from a school system that may have differed greatly from the American school system. Curricula, norm behaviors, and values may vary significantly (Ortiz, Flanagan \& Dynda, 2008). The structure, quality, and availability of educational services may be substantially different.

The GBG is commercially available and already owned by many school districts. Further, the procedures of the GBG can be implemented without the commercial game, and for little to no cost, in a variety of settings. A great deal of research supports the efficacy and acceptability of the GBG. The intervention is intended to reduce off-task and disruptive classroom behaviors, but the program may also have a significant positive impact on students' immediate and future emotional and behavioral well-being (e.g. Kellam et al., 2008). The potential long-term effects, relevance in consultation, manualdirected implementation, and feasibility as prevention, universal, and targeted intervention support the GBG as an ideal behavioral management technique for schools. Few limitations of the game have been identified, and those mentioned do not appear to detract from its effectiveness or utility. However, additional evidence is warranted to demonstrate the GBG's efficacy with ELLs. The low financial burden associated with implementation, as well as the low demand of language skills to participate, and the cooperative nature of the group contingency model, may make the GBG an excellent tool in settings such as urban areas with diverse populations and unique needs including limited resources. 
The goal of the current study is to address the lack of evidence-based interventions for diverse students by identifying empirically supported behavior management methods for use with ELLs. The researcher assessed the Good Behavior Game (GBG) and its efficacy with Latino ELLs (L-ELLs) by utilizing the program in a small group and monitoring the effect on the behavior of individual target students. The GBG served as a behavior management intervention for L-ELLs who are currently participating to a small peer group for safe school behavior. The curriculum of the peer group is unrelated to this study, and follows the standard of care at the school site. The curriculum addressed coping skills, problem solving, and positive prosocial behaviors such as taking turns. Lessons included a brief teacher led lesson, discussion, and a cooperative activity such as role play or a game.

The GBG was predicted to decrease the frequency of disruptive target behaviors in individual L-ELL students within a small peer group setting. It is the hope that the current study will inform educators about considerations for working with diverse populations like ELLs, and the evidence-based tools that are available to help them. Although the study tracks student behavior change, the GBG should not be considered treatment. The purpose of the GBG in this design is to improve students' participation and behavior during the group only, while the group curriculum would serve as the treatment for the behavior that results in discipline referrals. The hope is, by assessing the efficacy and appropriateness of a standard educational practice, the GBG, with ELLs in a small group setting, the results of this research may demonstrate the broad applicability of the GBG, including as a Tier II or III intervention, and contribute to the standard of practices for L-ELLs. 


\section{Research Questions}

The current study was designed with the hope of demonstrating the GBG's efficacy with culturally and linguistically diverse students, and its efficacy in the context of a small group, monitored at the level of the individual. The researchers identified two research questions to guide the development and interpretation of this project:

1. Is the Good Behavior Game effective with culturally and linguistically diverse students?

2. Is the Good Behavior Game effective in a small group setting? 


\section{CHAPTER II}

\section{METHODS}

\section{PARTICIPANTS AND SETTING}

The intervention was implemented at a large elementary school in the Northeast. The school is located in a small, urban area with less than 75,000 residents, where over $75 \%$ of students are eligible for free or reduced lunch. The school has a student body of nearly 800 in grades Pre-K through eight. The majority of families who attend this school are Latino. More than half of students speak Spanish, and 25\% of students currently receive services to develop English proficiency. Proficiency is determined by performance on an annual, district-wide assessment of oral and written English language ability, and progress is monitored via a quarterly, district-wide benchmark for all students currently receiving English development instruction. For the purpose of this study, students currently receiving such services are considered English Language Learners (ELLs).

\section{Sample}

Prior to the recruitment of this study, a number of boys and girls in grades three and four were referred by teachers for participation in a small peer group to address positive school behavior and play skills, based on their office discipline referral records. Parents previously agreed to group participation, which utilizes the school's standard of care curriculum and activities unrelated to this study. The researcher aimed to implement the current study within the existing small groups as a behavior management intervention during group sessions. Because students were recruited from this limited population, a convenience sample was obtained. Each group session contained three students, but only 
the single target student in each group was enrolled in the study, and data was only recorded and stored for the target student.

Recruited students were boys or girls in grades 3 or 4, currently receiving ELL instruction and participating in a peer group. Parents of six group participants were recruited via phone and mail. The researcher successfully made contact with parents of three students, and parents of two students returned signed consent (see Appendix A and B). The two students provided verbal assent (Appendix C) and were enrolled. The final two participants were boys in third grade. Both students were of Puerto Rican descent, and were receiving their third year of ELL instruction. Both had numerous discipline referrals for hands-on behavior, including hitting or kicking other students and rough play at recess, which led to their participation in a peer group. The boys also had previously been determined eligible for special education services, but received at least $80 \%$ of their instruction in a general education setting with at least $50 \%$ non-disabled peers. Neither student received services targeting behavior or social-emotional functioning outside of the current peer group. The target students were not significantly different from the peers in their groups; all students were boys or girls in grades 3 or 4, all were L-ELLs, and all had a similar history of behavior referrals.

\section{PROCEDURE}

\section{Materials}

The GBG was selected as the focus of this study, in part, for its low economic cost and minimal supply requirement. The following materials were utilized for this replication but trials have used a variety of data collection methods and materials in the 
past. For the present study, implementation required a timer to assure each group session was exactly 20 minutes in length to allow for comparison of frequency across sessions and between students. A checklist form was used to collect data and also to record implementation of each step of the procedure (see Appendix D and E). During the intervention phase, a visible dry-erase board was used to display the tally marks of behavior incidents during each session. During this phase, small, tangible, non-food items such as pencils or erasers were available as reinforcers.

\section{Design}

The study utilized a delayed, single-subject, multiple baseline A-B design. This design allows all groups to receive the intervention, while the staggered implementation allows the researchers to investigate the degree of change associated with the addition of the GBG. The design supports the prediction that if the target behavior changes only when the intervention has been introduced, then the effects can be attributed to the intervention rather than to extraneous events (Kazdin, 2011). Two students were enrolled in the study. They participated in two separate peer groups. Peer groups were assigned and established prior to this study, and utilized similar schedules and a curriculum based on the school's current standard of practice, and unrelated to the current research. During the baseline phase, students received only this standard of practice curriculum. During the intervention phase, students continued to receive the standard curriculum, but the GBG was introduced as a method of behavior management during the group. The GBG did not alter instruction during the group sessions.

Both groups convened on the same day, so that corresponding data points occurred on the same date. Data were collected during a total of eight sessions per group. 
After three data points of baseline, the intervention was introduced for five sessions. Baseline data collection occurred for three sessions in Student 1's group, followed by five sessions of intervention. Student 2's group began each phase after a lag of three data points. The order of intervention implementation was determined by convenience.

\section{Procedures}

For the purpose of this study, the threshold criteria was used to determine students' eligibility for a reward at the end of each session. The threshold criteria was selected over the team method due to the small group size and the odd number of students in each session. Each group worked as one team to minimize their disruptive behaviors and earn a reinforcer. The initial threshold was determined by selecting a number slightly lower than the current estimated frequency of disruptive behaviors, to make the goal reasonable to attain. During each subsequent intervention session, the threshold was lowered by one.

The researcher set a timer for 20 minutes at the start of each session. Students were aware of the timer and were informed that the timer alerts the students to prepare to return to class. During the baseline phase, the researcher used a checklist (Appendix D) to self-monitor fidelity of timing and data collection and to conduct behavior recording on a concealed clipboard. During the intervention phase, a separate implementation checklist was used (Appendix E). The timer was set for 20 minutes, and the start of Good Behavior Game was immediately announced. The two target behaviors were stated, and a dry-erase board was made visible to students. The board named the two behaviors, as well as the threshold or total behavior criteria for the session. Students were reminded that by not passing the threshold, or not exhibiting more behaviors than 
the criteria number, they were eligible to earn a reinforcer. For each target behavior observed, the researcher acknowledged the behavior verbally and by name in a neutral tone (e.g. "Student 2 interrupted his peer, that's a check."), and recorded the behavior on the board. Behaviors exhibited by the target student were recorded within the group total and also individually on a concealed clipboard. During the session, unrelated group activities and curricula were provided as is standard of care at the elementary school. As instructed in the GBG manual, occasional praise statements were used to acknowledge positive behavior during the intervention phase. At the conclusion of the 20 minute session, the researcher announced the game was over, and presented the total number of observed behaviors. Students were informed if they earned a prize, or if they had exceeded the threshold.

\section{Treatment Fidelity}

The researcher developed and followed an implementation checklist of all steps required for the present design to standardize treatment fidelity (see Appendices D and E). The checklist was adapted from administration guidelines of the commercial GBG manual, adapted for use with a small group and single team design. A separate checklist was created for baseline and intervention phases. The appropriate checklist was used for every data point for each group.

\section{Outcome Measures}

\section{Dependent Variables}


Prior to recruitment, all students referred for peer groups were observed by the researcher, as is the standard of care at the school. Interrupting and out-of-seat behaviors were identified as appropriate target behaviors because both behaviors were observed in a number of academic settings, and both behaviors were observed to be demonstrated by most group participants. Based on the commonality of the behaviors, the researcher anticipated the behaviors were likely to occur frequently in the small groups as well.

The independent variable of the current study is the implementation of GBG during the intervention phases. The dependent variable is the frequency of each disruptive behavior. Interrupting is operationally defined as speaking during another student or adult's statement, or responding when another student or adult is directly called upon. Interrupting does not include answering a question addressed to the whole group. Out of seat behavior is defined as separation from one's seat, including standing, rising to adjust one's position, or leaving one's assigned seat or area. Out of seat behavior does not include shifting or rocking in one's seat. Behaviors were defined for the student at the initial introduction of the GBG.

\section{Observation Procedures}

Behavior data was collected using event recording to obtain the frequency of each of two target disruptive behaviors during each timed, twenty minute group session only. The researcher collected target student frequency data on a record form on a concealed clipboard during baseline sessions. During the intervention session, group data was also recorded with a tally mark on a visible dry erase board for students' monitoring. Because other group participants were not enrolled subjects in the present study, this data was not 
collected or stored after each group session, and is not included in the results of this study. Analyses include data for the individual target student only.

\section{Data Analysis}

Data are collected and analyzed at the individual level for the target students. The dependent variable, frequency of disruptive behavior, is plotted on a line graph for visual analysis (Gast, 2010). The stability of level, trend, and variability within and across phases is assessed visually. Effect sizes are calculated using two overlap-based approaches, the Non-overlap of All Pairs (NAP), and Tau-U. NAP expands the analysis of overlap beyond the traditional percentage of non-overlapping data or PND (Parker \& Vannest, 2009). Tau-U accounts for the change in level from phase A to phase B, and incorporates the trend of phase $\mathrm{B}$, while controlling for the potential of a positive trend in phase A (Parker, Vannest, Davis \& Sauber, 2011). Finally, the Approach One: No Assumptions Model is utilized to calculate the magnitude of change between phases (Busk \& Serlin, 1992): $d=\left(\right.$ mean $\mathrm{A}_{2}-$ mean $\left.\mathrm{A}_{1}\right) /\left(\mathrm{SD} \mathrm{A}_{1}\right)$, where $\mathrm{A}_{1}$ represents the baseline, and $\mathrm{A}_{2}$ represents the intervention phase. 


\section{CHAPTER III}

\section{RESULTS}

The following results aim to analyze the effectiveness of a behavioral management intervention, Good Behavior Game, on the reduction of disruptive behaviors in a small group setting, with students who are ELs. The investigation measured the influence of the intervention on the frequency of two target behaviors in a single-subject, multiple baseline design. Data was collected through direct observation of two students placed in separate small peer groups which were facilitated by the researcher. A total of eight sessions per group were monitored, at the level of the individual student. The activities and curriculum of the group followed the standard of care of the school site, and addressed problem solving, coping skills, and prosocial behavior. The content of the group was not a variable of the current study. Two disruptive behaviors were identified and targeted by the intervention, and monitored during each session: interrupting and outof-seat behavior.

\section{ATTRITION}

The two enrolled students each completed the 8 scheduled sessions with their assigned group. Parents of six students eligible for participation were initially contacted. Successful contact was made with three parents, and of these, only two returned signed consent. The researcher recruited six participants, anticipating a high rate of attrition or limited response. While the desired minimum sample was three students, the final sample contained only two students. No students were removed from the study following consent and assent. The two enrolled students participated for the entire duration of the 
study.

\section{REDUCTION OF DISRUPTIVE BEHAVIORS}

\section{Interrupting}

Interrupting was operationally defined as speaking during another's statement, or responding when another is directly called upon. Interrupting did not include answering a question addressed to the whole group. Data presented is based on event recording of the frequency of interruptions made during each session. Each baseline and intervention phase was timed to last exactly 20 minutes. During one intervention session, Student 1 asked to use the restroom. The timer was stopped, and instruction and intervention were halted. When the student returned to the room, the timer was restarted and the GBG reannounced. The session continued again until the timer sounded, indicating the group had played the GBG for a cumulative 20 minutes not counting Student 1's restroom break. The data presented are a frequency count, given that all sessions are equal in length.

\section{Visual Analysis}

Graphical representation of interrupting behavior is provided in Figure 1 for Students 1 and 2. As illustrated, Student 1's behavior showed minimal variability and consistent trend direction. While the continuous negative trend line in the intervention phase is appropriate and desired with intervention to reduce behavior incidence, the baseline phase features a similar negative trend. Based on both mean and median, the level of the data fell $50 \%$ from baseline to intervention phase.

\section{Effect Sizes}

Overlap is calculated using the Non-overlap of All Pairs (NAP) and Tau-U methods. In the case of the present study, the effect size represents the probability that a 
data point selected at random from the phase baseline will be less than a data point selected at random from the intervention phase. NAP allows researchers to explore overlap in greater depth than the traditional percentage of non-overlapping data by considering change from all baseline points, as opposed to only the most-outlying point. Advantages of NAP include less room for human error, greater discrimination within or between single case studies, stronger validation by both visual analysis and $R^{2}$, and narrower confidence intervals which reflect greater precision (Parker \& Vannest, 2009). The score is calculated by identifying the total number of possible pairs of data points, and determining number of pairs that would not overlap. Parker and Vannest's (2009) report included NAP calculations of over 200 A-B contrasts. Based on results, they estimate effect sizes at or below 0.65 suggest a weak effect, and scores below 0.50 suggest a deterioration of performance following intervention implementation. Effect sizes ranging from 0.66 to 0.92 represent a moderate effect, and scores at or above 0.92 are large. For Student 1, the NAP effect size is 0.73 . For Student 2, the NAP is 0.83 . Based on their interpretation, the effect of the intervention is moderate for both students.

Tau-U allows researchers to assess both the overlap or level of phase A and B, and the trend of phase B. The effect size allows for the control of a potential trend of phase $\mathrm{A}$ in the direction of the desired outcome (in this case, negative), and also the limited credibility of a trend associated with a short length of phase A. The method also gives equal weight to each data point within a phase. For Student 1, the Tau-U effect size is 0.47 . For Student 2 , the effect is 0.67 .

Based on the method presented by Busk and Serlin (1992), effect sizes were calculated using the Approach One: No Assumptions Model to measure the strength of 
the relationship between the GBG intervention and reduction in interrupting behavior. This model was selected for the lack of assumptions about the distribution of data points within each phase. The calculation takes the difference of intervention mean less the baseline mean, and divides the result by the variance of the baseline mean. Calculations are presented in Table 1. The observed change in behavior resulted in an effect size of 0.71 for Student 1 and an effect size of -0.56 for Student 2. Results indicate a moderate effect, and the negative number indicated a desired direction of change, or reduction in frequency of interrupting behavior for both students.

\section{Out-of-Seat Behavior}

Out of seat behavior is defined as separation from one's seat, including standing, rising to adjust one's position, or leaving one's assigned seat or area. Out of seat behavior does not include shifting or rocking in one's seat. Data presented is based on event recording of the frequency of interruptions made during each 20 minute session.

\section{Visual Analysis}

Graphical representation of out-of-seat behavior is provided in Figure 2 for Students 1 and 2. For both students, the range of incidents per session of out-of-seat behavior is $0-1$, whether is baseline or intervention phase. While the data of both students demonstrates low variability and low levels during intervention phases, there is no observable difference in level by mean or median. Additionally, the estimated slope of the baseline and intervention trend lines are very similar for Student 1. Overall, visual analysis does not indicate an observable reduction in out-of-seat behavior for either student across phase.

\section{Effect Size}


Overlap-based effect sizes were calculated for out-of-seat behavior as well. The observed change in behavior for Student 1 resulted in a NAP effect size of 0.37 . For Student 2 , the effect size is 0.57 . The Tau-U effect size for is -0.27 for Student 1 , and 0.13 for Student 2. These scores suggest that the effects obtained for both students for out-of-seat behavior are small, and Student 1 may represent a deterioration of performance over time.

The Approach One: No Assumptions Model was employed again to measure the strength of the relationship between the GBG intervention and reduction in out-of-seat behavior for both students. Calculations are presented in Table 2. The observed change in Student 1's behavior resulted in an effect size of 0.23 , which is considered small. The out-of-seat behavior of Student 2 resulted in an effect size of -0.59 . While a result of this size suggests a moderate effect in the desired, decreasing direction, a review of visual analysis illustrates the minimal change in observation of Student 2's out of seat behavior, and a lack of overall significance for both students.

\section{TREATMENT FIDELITY}

The procedure was guided by implementation checklists, which were adapted from the commercial GBG manual to standardize administration and recording. The implementation checklist included under Appendix D was used in 100\% of baseline sessions, and $100 \%$ of steps were completed and checked off within each session. During the Intervention phase, the checklist under Appendix E was used in 100\% of sessions for both students. All steps were completed and checked off in all five sessions for both students. 


\section{CHAPTER IV}

\section{DISCUSSION}

As reviewed above, the GBG has an extensive research base with a range of ages and positive outcomes. The novel feature of the present study is the specific population targeted, ELLs, and the utility in a small group context, with assessment at the level of the individual. The use of a single subject design, monitored at the level of the individual, meant that the results reflected the change in the individual target L-ELL student, within the small group context. Participants were previously assigned to small peer groups of three students, in which the GBG was implemented to reduce disruptive behaviors during the group sessions. A delayed, multiple baseline, A-B design was employed, and event recording was used to measure the change in frequency of disruptive behavior for the target participant. The researcher sought to answer two questions: Is the GBG effective with culturally and linguistically diverse students, and does it work in a small group setting? It was hypothesized that the GBG would be effective with L-ELLs. Further, the implementation of the GBG as a behavior management strategy within a small group was predicted to reduce the frequency of two disruptive behaviors, interrupting and out-of-seat behavior.

Both students completed each phase in entirety. Checklists were also used consistently and with fidelity. Additionally, students were engaged in the focus of the game, and held one another accountable for their actions. Students were motivated to not exceed the threshold, and reminded one another if the group total was approaching the criterion (e.g. "Guys, we can only get two more marks!"). The intervention was easily 
implemented and data was easily recorded during both phases. Students adapted well to the expectation and appeared to understand the target behaviors, as well as their responsibility. All group participants appeared to enjoy the use of the game and verbalized disappointment at the conclusion of the intervention. Student 1 and his group earned a reinforcer on four out of five intervention sessions. Student 2 and his group earned the reinforcer on three out of five sessions.

\section{EFFECTS OF THE GOOD BEHAVIOR GAME ON BEHAVIOR \\ Interrupting}

A review of Student 1's data indicates he displayed an average of 2.3 behaviors (or median of 2) during the baseline phase, and an average of 1.2 behaviors (or median of 1) during intervention. By either calculation, the level of behavior during baseline was approximately twice as high as during intervention. In other words, the start of the GBG was associated with a 50\% reduction of interrupting behaviors. As presented in Table 1, results earned effect sizes of -0.47-0.73, suggesting Student 1 exhibited a moderate reduction in interrupting. Student 2 reduced his frequency of interrupting from a median

of 12 to a median of 7, but earned a somewhat weaker effect size of -0.56 when analyzed via the Approach One calculation. The overlap approaches resulted in effect sizes of .67 and 0.83 , which suggest a moderate effect. For both students, outcomes suggest that the implementation of the GBG was associated with a reduction in the target behavior of interrupting. Results suggest support for the hypothesis that the GBG can promote a reduction in interrupting behavior with moderate significance.

\section{Out-of-Seat Behavior}


Both students demonstrated few out-of-seat behaviors throughout both phases. Minor variances in occurrence across participants resulted in notably different effect size scores. As shown in Table 2, Student 1 earned small effect sizes, which suggests a minimal effect, or limited change in out-of-seat behavior in response to the intervention. According to Parker and Vannest (2009), a NAP effect size of this size may reflect a deterioration following implementation of the intervention, or in this case, an increase in behavior following the introduction of the GBG. The sign of the No Assumptions and Tau-U scores also reflects that the trend or change in the data is in contrast to the predicted outcomes. Student 2 earned scores of -0.59 (No Assumptions) and 0.57 (NAP), which reflects a moderate reduction in behavior. However, both students left their seat zero or one times per session. The calculated effect sizes in this case, are attempting to gauge a change within a small window of movement, when in reality the data reflects a behavior that was nearly nonexistent pre-intervention, and therefore did not have much room to change. In this case the Tau-U method obtained a small score, reflecting the minimal impact of the intervention on the behavior. Additionally, because of the slight increase in observation of Student 1's out-of-seat behavior during the intervention phase (three out of five sessions) compared to the baseline phase (one out of three sessions), the Approach One effect size is positive, which suggests there was a small increase in incidence, the Tau-U score is negative, which suggests a change in the opposite direction than predicted, and the NAP effect size is less than 0.50 , which also suggests deterioration of performance (Parker \& Vannest, 2009). Therefore the results indicate the opposite of the desired outcome, or an increase in out-of-seat behavior. This is a 
circumstance where the visual analysis provides information more illustrative of the outcome than the effect size.

\section{IMPLICATIONS}

The present study primarily aimed to assess the GBG as an effective and appropriate behavior intervention for L-ELLs. Although complicated by a small sample size and inconsistent effects, the results of this study suggest that the GBG should be further investigated with culturally and linguistically diverse students such as L-ELLs. While the present data offers only emerging support, the expansive history of the GBG and the utility of the GBG with students with unique backgrounds and needs implies that further research would be valuable to establishing the evidence base for L-ELLs, and for

identifying the GBG as a sound intervention for this unique population. Additionally, the mass availability of the commercial game, and well as the ability to implement the GBG in its original form, make it an excellent vehicle for further assessment in novel settings and with previously uninvestigated contexts.

A second focus of the study is the implementation of the GBG in a small group. Upson and Skinner (2002) demonstrated efficacy at the level of the individual, and illustrated a means of using the program with a small subset of students who require targeted supports as opposed to class-wide or universal supports. This study aimed to build upon this application of the GBG within other tiers of Response-to-Intervention by assessing the game in a small, non-classroom setting. While the results are preliminary, the outcomes suggest the GBG may be successful when introduced to a small group setting. 


\section{Limitations.}

While the current study aimed to recruit L-ELLs from a number of different backgrounds, the enrolled sample was very homogenous, including only two students of Puerto Rican descent. The students also shared the same age, grade, and eligibility for special education services. While homogeneity is a desired characteristic of experimental research, it is a limitation of single subject designs in general that such a small subgroup of the target population is analyzed in one trial. Latinos represent the largest subgroup of ELLs in the U.S., and in school-age populations in particular. The results of this study may not generalize to all L-ELLs. This study also used a small convenience sample, which may also limit the generalizability of the results, in particular to other regions of the U.S., other ages or other behavioral needs. Additionally, the reliance on singlesubject design limits the effect sizes available to calculate the impact of the intervention.

The length of the intervention was kept brief to correspond with the implementation schedule of the pre-established peer groups. The standard of care at the school that served as the recruitment site is six to eight weeks for counseling not mandated by a formalized special education or 504 program. Another limitation of the design was the lack of interobserver agreement (IOA) to assess accuracy in data collection. While the study included a measure to ensure fidelity to the intervention procedures, a second, objective coder was unavailable to assess the accuracy of data reporting, due to necessary changes in group scheduling to accommodate student attendance and discipline. While IOA is considered a standard component of research, and was actively sought by the researcher, systematic review of research of the GBG finds that inclusion of treatment fidelity procedures does not appear to impact the 
efficacy of the study (Flower, McKenna, Bunuan, et al., 2014). Their review of 22 studies of the GBG found that only 8 included measures to assess fidelity of implementation. Results indicated there was no discernable difference in the size of the effect between studies that did consider treatment fidelity and those that did not. The effect of the intervention was consistently moderate to large across both groups of studies.

While no enrolled students were exited or withdrawn before the conclusion of the study, the recruitment of the desired three to six students was not achieved due to lack of parental contact and feedback. Parents of six students were initially recruited, but contact could only be made with three parents, and only two of the contacted parents returned signed consent.

The two disruptive behaviors that were monitored and recorded during this intervention were selected based on classroom observations of students referred for peer groups. While this practice ensured that the behaviors were actions frequently exhibited by all group participants, it did not guarantee the observation of the behaviors in small group. The context of a small peer group differs substantially from a regular education classroom setting. While both settings may involve adult-led instruction, cooperative discussion or work, and table work, the small group setting of the researcher's office eliminates many sources of distraction. The small group also increases the perceived level of adult attention and supervision. While task demands were made in the group setting, the perceived difficulty or challenge, as well as the duration of the activities, was significantly more likely to be well-managed by all participants. Interrupting behavior was common both in classrooms and in the group setting, but out of seat behavior was less common. When tracking data at the level of the individual, the initial incidence was 
so infrequent, analyses were not truly reflective of the potential impact of the intervention. Finally, most students appeared motivated to attend group and to remain in the group, perhaps as a means of escaping the demands of the classroom, which may have indirectly or intrinsically promoted staying in one's seat.

An unforeseen complication was the potential for disciplinary action for students engaged in the group. Both students were suspended in school during the study on group days, but were given permission by administrators to leave the in-school suspension room to attend the group, as the function and curriculum of the group targeted the behavior which resulted in the disciplinary action. Student 1 also received out-of-school suspension for three consecutive days, which required rescheduling the date of both groups. The region of the selected school is a small urban area, and the population from which the sample is drawn includes a significant portion of families from lower socioeconomic backgrounds, as well as ethnic minorities, immigrants, and non-English speaking parents. These population have a history of higher rates of transience in comparison with majority populations in suburban areas. Many students transition into and out of the district within the typical school year. Attendance was also an issue, which reflects a persistent challenge in this school district, as well as many urban districts. While the researcher speaks fluent Spanish and all communication and study documents were provided in English and Spanish, consistent home-school communication is occasionally a challenge in this region.

\section{Future Directions}


While some moderate effects were observed, admittedly minimal generalizations can be made based on these results due to the limited data. Nevertheless, the importance of considering diverse populations is essential to determining the generalizability of success with any intervention. The potential utility of the GBG with unique populations and settings is supported by the minimal verbal and reading demands of the intervention, the inclusion of a group contingency component, and the ease of implementation with students with a range of abilities and needs and in a range of contexts. Future research may include continued replication of the GBG in culturally and linguistically diverse classrooms, in particular with growing minority groups and ELLs from other cultural backgrounds.

With respect to ELLs as a research sample, investigators should take care to address the limitations noted above, as they reflect the unique difficulties of engaging culturally and linguistically diverse populations in the educational environment. When translating documents or providing services in other languages, it is vital to ensure the consistency of the content by conducting translations and back-translations, by considering the writing ability of native speaker translators, and considering the reading level of the recipients. The current pattern home-school communication may provide an indicator of the ease of contacting and engaging parents to consider research participation. For example, investigators should consider the dominant language of the desired sample population, and the presence of educators who speak the language and are able to contact parents successfully. Parents who are only contacted to receive suspension notice will likely be less responsive than parents who communicate with teachers regularly for neutral circumstances. Finally, awareness of community resources 
may help parents minimize absences and reduce the risk of displacement while building rapport and a community of collaboration with families.

\section{SUMMARY}

Evidence based interventions for L-ELLs are lacking, although there is a significant need for effective, empirically-supported methods with this growing population. The limited research available on cultural differences and social behaviors for L-ELLs suggests that a group contingency with visual cues such as the GBG may be a good fit for their unique experiences and needs. The GBG has an extensive research base with a range of ages and positive outcomes. The novel feature of the present study is the specific population targeted, ELLs, and the utility in a small group context, with assessment at the level of the individual. Participants were previously assigned to small peer groups of three students. The GBG was identified as an intervention to reduce disruptive behaviors during the group sessions. A delayed, multiple baseline, A-B design was employed, and event recording was used to measure the change in frequency of disruptive behavior for the target participant. The small convenience sample included two boys in grade 3, identified as L-ELLs and currently receiving ELL instruction, and referred to the peer group for behavior. Two target behaviors were monitored: interrupting and out-of-seat behavior. While there was little incidence of out-of-seat behavior for either participant during the baseline phase (and therefore little application of the small-to-moderate effect sizes), both student demonstrated a change in frequency of interrupting. Effect sizes indicate a moderate reduction in interruptive behavior of 0.71 and 0.73 for Student 1 , and -0.56 and 0.83 for Student 2. The limitations of the 
investigation include the small convenience sample (and associated low recruitment), the exclusion of ELLs of other cultural backgrounds or native languages, and the brief duration of the study. Future research should include other ELL groups, additional ages, and larger samples to support the preliminary results obtained in this study. The effect, while only small to moderate, suggests that continued evaluation of the GBG and similar interventions has the potential to significantly expand the research base for Latino and ELL educational strategies. 


\section{REFERENCES}

American Federation of Teachers. (2000). Building on the best, learning from what works: Five promising discipline and violence prevention programs.

Washington, DC: Author.

Aud, S., Fox, M., and KewalRamani, A. (2010). Status and Trends in the Education of Racial and Ethnic Groups (NCES 2010-015). U.S. Department of Education, National Center for Education Statistics. Washington, DC: U.S. Government Printing Office.

Babyak, A. E., Luze, G. J., \& Kamps, D. M. (2000). The Good Student Game: Behavior management for diverse classrooms. Interventions in the School and Clinic, 35, $216-223$.

Barrish, H. H., Saunders, M, \& Wold, M. M. (1969). Good behavior Game: Effects of individual contingencies for group consequences on disruptive behavior in a classroom. Journal of Applied Behavior Analysis, 2, 119-124.

Becker, K. D., Bradshaw, C. P., Domitrovich, C., \& Ialongo, N. S. (2013). Coaching teachers to improve implementation of the good behavior game. Administration and Policy in Mental Health and Mental Health Services Research, 40(6), 482493.

Bradshaw, C. P., Zmuda, J. H., Kellam, S., G., \& Ialongo, N. H. (2009). Longitudinal impact of two universal preventive interventions in first grade on educational outcomes in high school. Journal of Educational Psychology, 101, 926-937. 
Burns, B. J., Costello, E. J., Angold, A., Tweed, D., Stangl, D., Farmer, E., \& Erkanli, A. (1995). Children's mental health service use across service sectors. Health Affairs, 14, 147-159.

Busk, P. L., \& Serlin, R. C. (1992). Meta-analysis for single-case research. In T. R. Kratochwill, \& J. R. Levin (Eds.), Single Case Research Design and Analysis: New Directions for Psychology and Education (pp. 187-212). Hillsdale, NJ: Lawrence Erlbaum.

Conroy, M., Sutherland, K., Snyder, A., \& Marsh, S. (2008). Classwide interventions. Teaching Exceptional Children, 40, 24-30.

Cooper, J. O., Heron, T. E. \& Heward, W. L. (2007). Applied behavior analysis, $2^{\text {nd }}$ ed. Pearson Education, Inc.: Upper Saddle River, New Jersey.

Dion, E., Roux, C., Landry, D., Fuchs, D., Wehby, J., \& Dupéré, V. (2011). Improving attention and preventing reading difficulties among low-income first-graders: A randomized study. Prevention Science, 12, 70-79.

Donaldson, J. M., Vollmer, T. R., Krous, T. Downs, S., \& Berard K. P. (2011). An evaluation of the Good Behavior Game in kindergarten classrooms. Journal of Applied Behavioral Analysis, 44, 605-609.

Embry, D. (2002). The Good Behavior Game: A best practice candidate as a universal behavioral vaccine. Clinical Child and Family Psychology Review, 5, 273-297.

Embry, D. (2004). Mi magnífica escuela PAX: Cómo el Juego PAX de Buena Conducta cambió a mi clase, a mi escuela y a mi mundo [My magnificent PAX school: How the PAX Good Behavior Game changed my class, my school and my world]. Tuscon, AZ: PAXIS Institute. Retrieved 10/27/2009 from 
http://www.hazelden.org/web/public/spanishpreventiondownload.pagehttp://ww w.hazelden.org/web/public/spanishpreventiondownload.page

Embry, D., \& Straatemeier, G. (2001). The PAX Acts GameManual: How to apply the Good Behavior Game. Tucson, AZ: PAXIS Institute.

Flower, A., McKenna, J., Muething, C.S., Bryant, D. P., \& Bryant, B. R. (2014). Effects of the Good Behavior Game on classwide off-task behavior in a high school basic algebra resource classroom. Behavior Modification, 38, 45-68.

Flower, A., McKenna, J. W., Bunuan, R. L., Muething, C. S., \& Vega, Jr., R. (2014). Effects of the Good Behavior Game on challenging behaviors in school settings. Review of Educational Research, 84, 546-571.

Frazier, S. L., Chacko, A., Van Gessel, C., O’Boyle, C., \& Pelham, W. E. (2012). The summer treatment program meets the south side of Chicago: Bridging science and service in urban after-school programs. Child and Adolescent Mental Health, 17, 86-92.

Gast, D. (2010). Single Subject Research Methodology in Behavioral Sciences. New York, New York: Routledge, Taylor and Francis Group.

Gresham, F.M. (2004). Current status and future directions of school-based behavioral interventions. School Psychology Review, 33, 326-343.

Grunewald, S., Shriberg, D., Wheeler, A. S., Halsell Miranda, A., O’Bryon, E. C., \& Rogers, M. R. (2014). Examining diversity research literature in school psychology from 2004-2010. Psychology in the Schools, 55, 421-433. 
Harris, V. W. \& Sherman, J. A. (1973). Use and analysis of the "Good Behavior Game" to reduce disruptive classroom behavior. Journal of Applied Behavior Analysis, 6, 405-417.

Huber, H. (1979). The value of a behavior modification programme, administered in a fourth grade class of a remedial school. Praxis der Kinderpsychologie und Kinderpsychiatrie, 28, 73-79.

Huizink, A. C., van Lier, P. A. C., \& Crijnen, A. A. M. (2009). Attention deficit hyperactivity disorder symptoms mediate early-onset smoking. European Addiction Research, 15, 1-9.

Kazdin, A. E. (2011). Single-case research designs: Methods for clinical and applied settings. ( $2^{\text {nd }}$ ed.). New York: Oxford University Press, Inc.

Kellam, S., Anthony, J. (1998). Targeting early antecedents to prevent tobacco smoking: Findings from an epidemiologically based randomized field trial. American Journal of Public Health, 88, 1490-1495.

Kellam, S., Brown, C., Poduska, J., Ialongo, N., Wang, W., Toyinbo, P., et al. (2008). Effects of a universal classroom behavior management program in first and second grades on young adult behavioral, psychiatric, and social outcomes. Drug and Alcohol Dependence, 95, S5-SS28.

Kellam, S., Ling, X., Merisca, R., Brown, C. H., \& Ialongo, N. (1998). The effect of the level of aggression in the first grade classroom on the course and malleability of aggressive behavior into middle school. Development and Psychopathology, 10, $165-185$. 
Kellam, S. G., Wang, W., MacKenzie, A. C. L., Brown, C. H., Ompad, D. C., Or, F., Ialongo, N. S., Poduska, J. M., Windham, A. (2014). The impact of the Good Behavior Game, a universal classroom-based preventive intervention in first and second grades, on high-risk sexual behaviors and drug abuse and dependence disorders into young adulthood. Prevention Science, 15, S6-S18.

Kleinman, K. E., \& Saigh, P. A. (2011). The effects of the Good Behavior Game on the conduct of regular education New York City high school students. Behavior Modification, 35, 95-105.

Kosiec, L. E., Czernicki, M. R., \& McLaughlin, T. F. (1986). The Good Behavior Game: A replication with consumer satisfaction in two regular elementary school classrooms. Techniques, 2, 15-23.

Lannie, A., \& McCurdy, B. (2007). Preventing disruptive behavior in the urban classroom: Effects of the Good Behavior Game on student and teacher behavior. Education and Treatment of Children, 30, 85-98.

Leflot, G., van Lier, P. A. C., Onghena, P., \& Colpin, H. (2010). The role of teacher behavior management in the development of disruptive behaviors: An intervention study with the Good Behavior Game. Journal of Abnormal Child Psychology, 38, 869-882.

Maggin, D. M., Johnson, A. H., Chafouleas, S. M., Ruberto, L. M., \& Berggren, M. (2012). A systematic evidence review of school-based group contingency interventions for students with challenging behavior. Journal of School Psychology, 50(5), 625-654. 
McCurdy, B. L., Lannie, A. L., \& Barnabas, E. (2009). Reducing disruptive behavior in an urban school cafeteria: An extension of the Good Behavior Game. Journal of School Psychology, 47, 39-545.

McGoey, K. E., Schneider, D. L., Rezzetano, K. M., Prodan, T., \& Tankersley, M. (2010). Classwide intervention to manage disruptive behavior in the kindergarten classroom. Journal of Applied School Psychology, 26, 247-261.

Medland, M. B. \& Stachnik, T. J. (1972). Good-behavior Game: A replication and systematic analysis. Journal of Applied Behavior Analysis, 5, 45-51.

Mejía-Arauz, R., Rogoff, B., Dexter, A., \& Najafi, B. (2007). Cultural variation in children's social organization. Child Development, 78, 1001-1014.

Nolan, J. D., Filter, K. J ., \& Houlihan, D. (2014). Preliminary report: An application of the Good Behavior Game in the developing nation of Belize. School Psychology International, 35, 421-428

Nolan, J. D., Houlihan, D., Wanzek, M., \& Jenson, W. R. (2014). The Good Behavior Game: A classroom-behavior intervention effective across cultures. School Psychology International, 35, 191-205

Ortiz, S. O., Flanagan, D. P. \& Dynda, A. M. (2008). Best Practices in Working with Culturally and Linguistically Diverse Children and Families. In A. Thomas \& J. Grimes (Eds.) Best Practices in School Psychology V, (pp. 1721-1738). Washington, DC: National Association of School Psychologists.

Parker, R. I. \& Vannest, K. (2009). An Improved Effect Size for Single-Case Research: Nonoverlap of All Pairs. Behavior Therapy, 40, 357-367. 
Parker, R. I., Vannest, K., Davis, J. L., \& Sauber, S. B. (2011). Combining nonoverlap and trend for single case research: Tau-U. Behavior Therapy, 42, 284-299.

Pérez, V., Fernández, A., Rodríguez, J., \& De la Barra, F. (2005). Efectividad de una estrategia conductual para el manejo de la agresividad en escolares de enseñanza básica. Psykhe: Revista de la Escuela de Psicología, 14, 55-62.

Petras, H., Kellam, S., Brown, C., Muthén, B., Ialongo, N., \& Poduska, J. (2008). Developmental epidemiological courses leading to antisocial personality disorder and violent and criminal behavior: Effects by young adulthood of a universal preventive intervention in first- and second-grade classrooms. Drug and Alcohol Dependence, 95, S45-SS59.

Phillips, D., \& Christie, F. (1986). Behaviour management in a secondary school classroom: Playing the game. Maladjustment and Therapeutic Education, 4(1), 47-53.

Poduska, J., Kellam, S., Wang, W., Brown, C., Ialongo, N., \& Toyinbo, P. (2008). Impact of the Good Behavior Game, a universal classroom-based behavior intervention, on young adult service use for problems with emotions, behavior, or drugs or alcohol. Drug and Alcohol Dependence, 95, S29-SS44.

Robertshaw, C. S., \& Hiebert, H. D. (1973). The astronaut game: A group contingency applied to a first grade classroom. School Applications of Learning Theory, 6, 2833.

Rones, M. \& Hoagwood, K. (2000). School-based mental health services: A research review. Clinical Child and Family Psychology Review, 2, 223-241. 
Ruiz-Olivares, R., Pino, M. J., \& Herruzo, J. (2010). Reduction of disruptive behaviors using an intervention based on the Good Behavior Game and the Do-Say-Report Correspondence. Psychology in the Schools, 47, 1046-1058.

Saigh, P., \& Umar, A. (1983). The effects of a Good Behavior Game on the disruptive behavior of Sudanese elementary school students. Journal of Applied Behavior Analysis, 16, 339-344.

Sanetti, L. M. H. \& Kratochwill, T. R. (2011). An evaluation of the Treatment Integrity Planning Protocol and two schedules of treatment integrity self-report: Impact on implementation and report accuracy. Journal of Educational and Psychological Consultation, 21, 284-308.

Spilt, J. L., Koot, J. M., \& van Lier, P. A. C. (2013). For whom does it work? Subgroup differences in the effects of a school-based universal prevention program. Prevention Science, 14, 479-488.

Swiezy, N. B., Matson, J. L., \& Box, P. (1992). The good behavior game: A token reinforcement system for preschoolers. Child and Family Behavior Therapy, 14, 21-32.

Tanol, G., Johnson, L., McComas, J., \& Cote, E. (2010). Responding to rule violations or rule following: A comparison of two versions of the Good Behavior Game with kindergarten students. Journal of School Psychology, 48, 337-355.

Tapia, J. (2004). Latino households and schooling: Economic and sociocultural factors affecting students' learning and academic performance. International Journal of Qualitative Studies in Education, 17, 415-436. 
Tingstrom, D. (1994). The Good Behavior Game: An investigation of teachers' acceptance. Psychology in the Schools, 31, 57-65.

Tingstrom, D. H., Sterling-Turner, H. E., \& Wilczynski, S. M. (2006). The Good Behavior Game: 1969-2002. Behavior Modification, 30, 225-253.

Upson, L., \& Skinner, C. (2002). A demonstration of class-wide data-based decision making. Inquiry: Critical Thinking Across the Disciplines, 21, 41-49.

van Lier, P., Muthén, B., van der Sar, R., \& Crijnen, A. (2004). Preventing disruptive behavior in elementary school children: Impact of a universal classroom-based intervention. Journal of Consulting and Clinical Psychology, 72, 467-478.

Van Lier, P. A. C., Vuijk, P., \& Crijnen, A. A. M. (2005). Understanding mechanisms of change in the development of antisocial behavior: The impact of a universal intervention. Journal of Abnormal Child Psychology, 33, 521-535.

Vuijk, P., van Lier, P. A. C., Crijnen, A. A. M., \& Huizink, A. C. (2007). Testing sexspecific pathways from peer victimization to anxiety and depression in early adolescents through a randomized intervention trial. Journal of Affective Disorders, 100, 221-226.

Walker, H. M. (2004). Commentary: Use of evidence-based interventions in schools: Where we've been, where we are, and where we need to go. School Psychology Review, 33, 398-407.

Wilcox, H., Kellam, S., Brown, C., Poduska, J., Ialongo, N., Wang, W., et al. (2008). The impact of two universal randomized first- and second-grade classroom interventions on young adult suicide ideation and attempts. Drug and Alcohol Dependence, 95, S60-SS73. 
Witvliet, M., van Lier, P., Cuijpers, P., \& Koot, H. (2009). Testing links between childhood positive peer relations and externalizing outcomes through a randomized controlled intervention study. Journal of Consulting and Clinical Psychology, 77, 905-915.

Wright, R. A. \& McCurdy, B. L. (2012). Classwide positive behavior support and group contingencies: Examining a positive variation of the Good Behavior Game. Journal of Positive Behavior Interventions, 14, 173-180. 
TABLE 1

Effect Size Calculations for Interrupting Behavior.

\begin{tabular}{lcccccc}
\hline & Mean $_{\mathbf{A}}$ & Mean $_{\mathbf{B}}$ & Variance $_{\mathbf{A}}$ & Approach One & NAP & Tau-U \\
\hline Student 1 & 2.3 & 1.2 & 1.56 & -0.71 & 0.73 & 0.47 \\
Student 2 & 0.3 & 7.2 & 5.56 & -0.56 & 0.83 & 0.67 \\
\hline
\end{tabular}


TABLE 2

Effect Size Calculations for Out-of-Seat Behavior.

\begin{tabular}{lcccccc}
\hline & Mean $_{\mathbf{A}}$ & Mean $_{B}$ & Variance $_{\mathbf{A}}$ & Approach One $^{\text {NAP }}$ & Tau-U \\
\hline Student 1 & 0.33 & 0.60 & 0.22 & 0.23 & 0.37 & -0.27 \\
Student 2 & 0.33 & 0.20 & 0.22 & -0.59 & 0.57 & 0.13 \\
\hline
\end{tabular}


FIGURE 1

Frequency of Interrupting Behaviors per Session

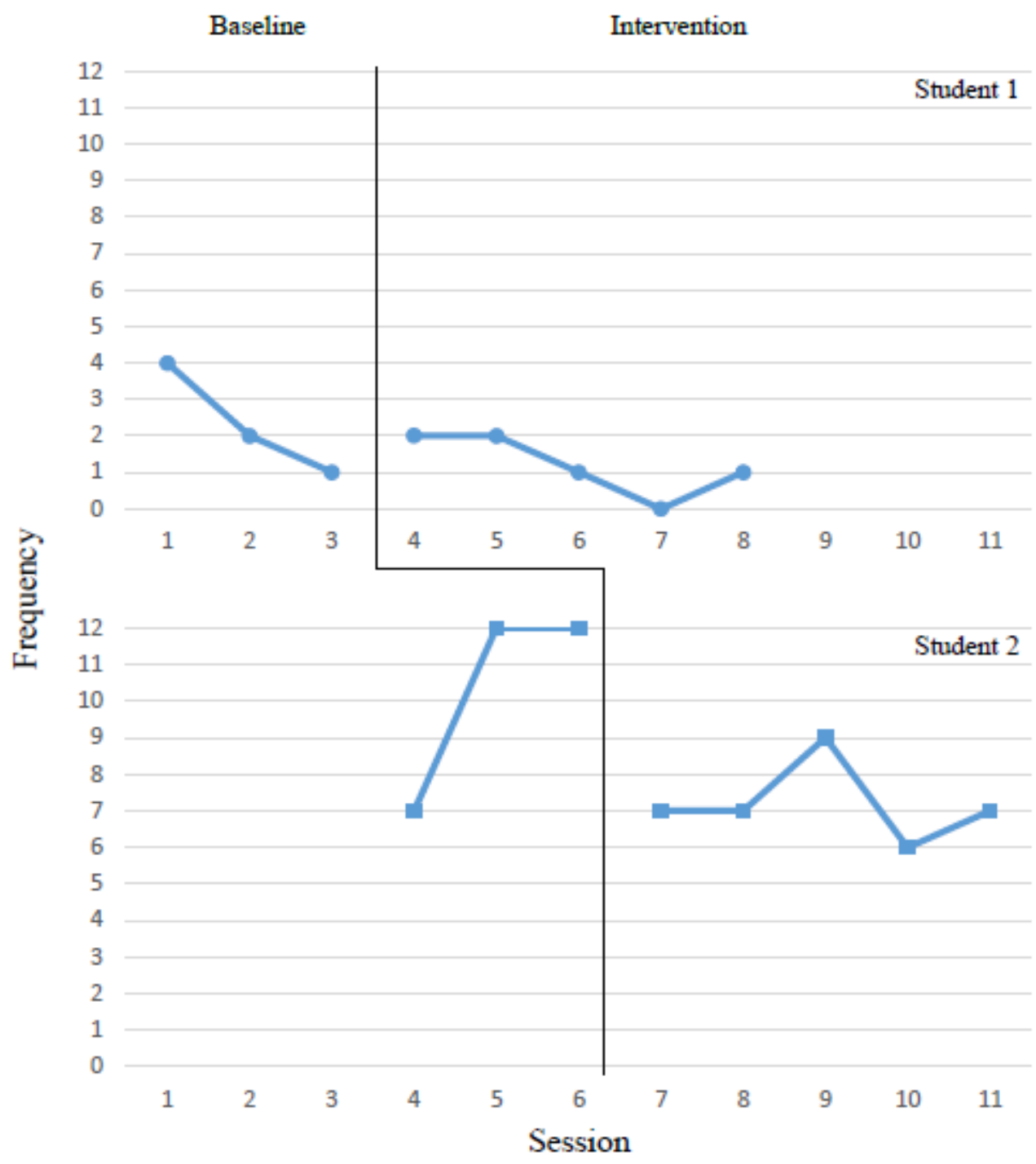


FIGURE 2

Frequency of Out of Seat Behaviors per Session

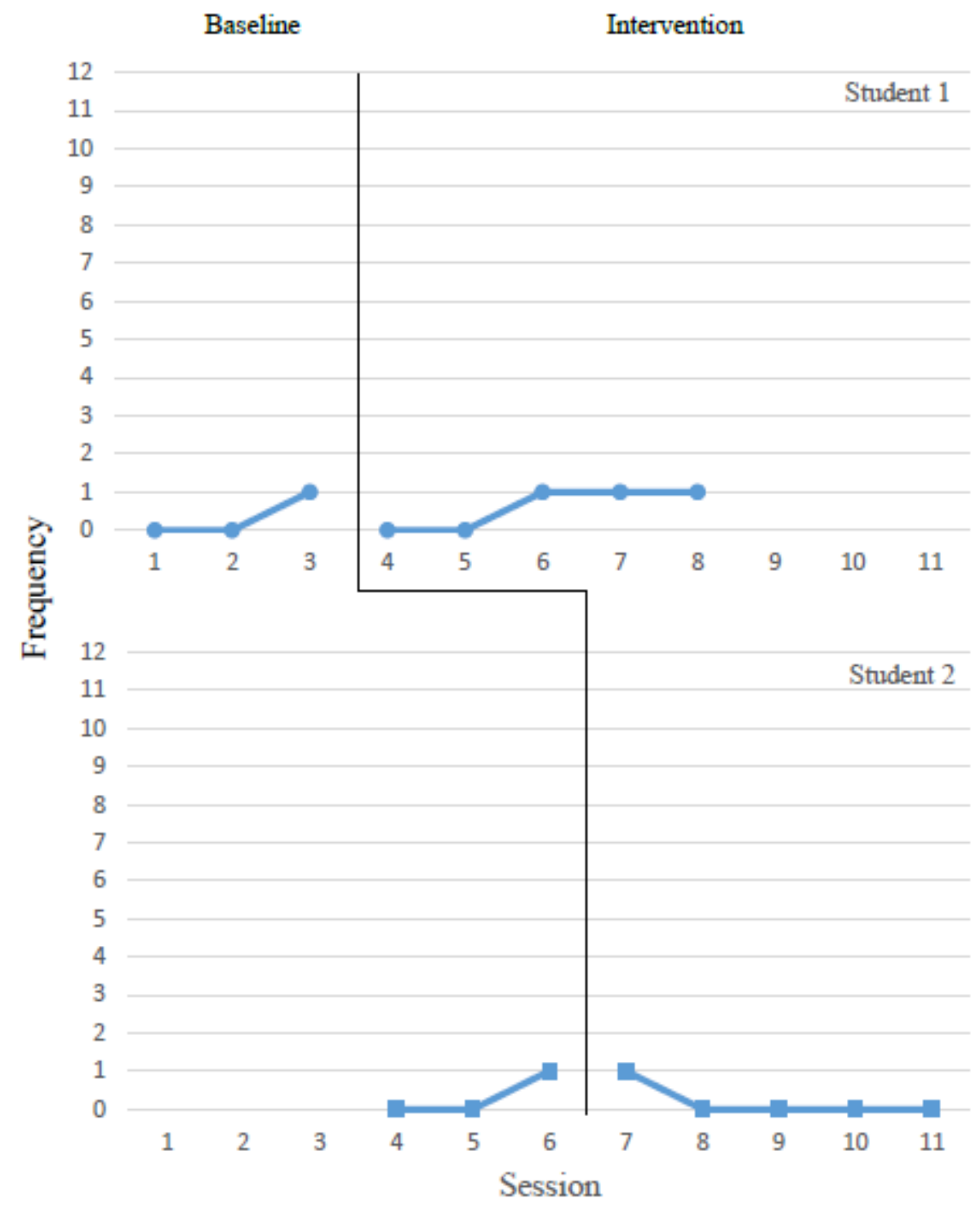

APPENDIX A 
Parental Permission Form, English 


\section{Parental Permission Form for Participation in a Research Study University of Connecticut}

Principal Investigator: Melissa Bray, $\mathrm{PhD}$

Student Researcher: Jennifer Ortiz, MA

Study Title: Good Behavior Game with ELLs in a Small Group Setting

\section{$\underline{\text { Introduction }}$}

Your child is invited to participate in a research study of a behavior intervention for English Language Learners (ELLs). Your child is being asked to participate because he/she is an ELL in elementary school.

\section{Why is this study being done?}

The purpose of this study is to see if a behavior intervention, the Good Behavior Game, is useful and appropriate for ELLs. This study can help the researchers understand the needs of diverse students, and identify successful methods for helping students whose second language is English.

What are the study procedures? What will my child be asked to do?

If you allow your child to participate in this study, your child's small group will utilize the Good Behavior Game (GBG) each day for 20 minutes. Your child will not have to do anything differently during this time. The school psychologist will monitor the group's behavior. This will continue for at least 8 sessions. The researchers ask your permission to monitor your child's behavior for this research study, to determine if GBG improves behavior in a small group.

What other options are there?

Your child does not have to participate in the study. Your child can still participate in the group, and no data will be recorded about your child's behavior. Your child can also participate in a group that does not use GBG.

What are the risks or inconveniences of the study?

There are no known risks to your child because of his/her participation in the study; however, a possible inconvenience may be the time it takes to complete the study. What are the benefits of the study?

Your child may not benefit directly. We hope to find ways to help educators of ELLs. Will my child receive payment for participation? Are there costs to participate? 
There are no costs to you and your child. Your child will not be paid to participate in this study. Students may earn small prizes.

\section{How will my child's information be protected?}

The researchers will keep all records locked in a secure location. All electronic files containing identifiable information will be password protected, on a locked computer. Only the researchers will have access to the passwords. No personal information about your child will be shared. At the end of the study, the researchers may publish the results. Your child will not be identified in any publications or presentations.

You should also know that the UConn Institutional Review Board (IRB) and the Office of Research Compliance may inspect study records as part of its auditing program, but these reviews will only focus on the researchers and not on your child's responses or involvement. The IRB is a group of people who review research studies to protect the rights and welfare of research participants.

\section{Can my child stop being in the study and what are my and my child's rights?}

Your child does not have to be in this study if you do not want him/her to participate. If you give permission for your child to be in the study, but later change your mind, you may withdraw your child at any time. There are no penalties or consequences of any kind if you decide that you do not want your child to participate. You will be notified of all significant new findings during the course of the study that may affect your willingness to allow your child to continue.

\section{Whom do I contact if I have questions about the study?}

Take as long as you like before you make a decision. We will be happy to answer any question you have about the study. If you have other questions about this study or if you have a research-related problem, you may contact the principal investigator, Dr. Melissa Bray (860-486-0167) or the student researcher, Jennifer Ortiz (203-988-3613). If you have any questions concerning your child's rights as a research participant, you may contact the University of Connecticut Institutional Review Board (IRB) at 860-486-8802. 


\section{Parental Permission Form for Participation in a Research Study Wniversity of Connecticut}

Principal Investigator: Melissa Bray, $\mathrm{PhD}$

Student Researcher: Jennifer Ortiz, MA

Study Title: Good Behavior Game as a behavior strategy for ELLs

\section{Documentation of Permission:}

I have read this form and decided that I will give permission for my child to participate in the study described above. Its general purposes, the particulars of my child's involvement and possible risks and inconveniences have been explained to my satisfaction. I understand that I can withdraw my child at any time. My signature also indicates that I have received a copy of this parental permission form.

You may keep this form, and only return this signature page to your child's teacher by

Name of Student:

Parent/Guardian Signature:

Print Name:

Date:

Relationship to Child (e.g. mother, father, guardian):

Signature of Person

Print Name:

Date:

Obtaining Consent 
APPENDIX B

Parental Permission Form, Spanish 


\title{
Permiso Parental para Participar en un Estudio de Investigación
}

\section{Wuniversity of Connecticut}

\author{
Investigadora Principal: Melissa Bray, $\mathrm{PhD}$ \\ Investigadora Estudiantil: Jennifer Ortiz, MA \\ Título del Estudio: El Juego de Buena Conducta como una estrategia de \\ comportamiento para estudiantes de inglés.
}

\section{Introducción}

Su hijo/a es invitado a participar en un estudio de investigación sobre una intervención de comportamiento para los estudiantes cuyo segundo idioma es el inglés. Se pide su participación debido a que su hijo/a estudia inglés en una escuela primaria.

\section{Por qué se hace este estudio?}

El propósito de este estudio es ver si una intervención de comportamiento, el Juego de Buena Conducta, es útil y adecuada para estudiantes cuyo segundo idioma es el inglés. Este estudio puede ayudar a las investigadoras a entender las necesidades de los estudiantes diversos e identificar los métodos más apropiados para ayudar a los estudiantes cuyo segundo idioma es el inglés.

¿Cuáles son los procedimientos de estudio? ¿Qué se le pedirá a mi hijo/a que haga?

Si permite a su hijo/a a participar en este estudio, su grupo pequeño utilizará el Juego de Buena Conducta (JBC) cada sesión for 20 minutos. Su hijo no tendrá que hacer algo diferente durante este tiempo. La psicóloga escolar observará el comportamiento del grupo. Esta continuará al menos que 8 sesiones. Las investigadoras piden su permiso para documentar la conducta del grupo para el estudio de investigación, para determinar si el JBC mejora la conducta en un grupo pequeño.

¿Qué otras opciones existen?

La participación de su hijo/a no es obligatoria. Su hijo/a puede participar en el grupo, y no se documentarán los datos de su conducta. También su hijo/a pedue participar en otro grupo $\sin \mathrm{JBC}$.

¿Cuáles son los riesgos o inconvenientes del estudio?

Creemos que su hijo/a no corre ningún riesgo conocido por participar en el estudio de investigación; Sin embargo, un inconveniente podría ser el tiempo necesario para completar el estudio.

¿Cuáles son los beneficios del estudio?

Es posible que su hijo no beneficiarse directamente. Esperamos encontrar metodos de ayudar a los educadores de los estudiantes cuyo segundo idioma es el inglés . 


\section{¿Mi hijo/a recibirá pago por su participación? ¿Hay costos para participar?}

No hay costos para usted y su hijo. Su hijo no recibirá ningún pago monetario por participar en este estudio. Estudiantes pueden ganar premios pequeños.

¿Cómo se protegerá la información de mi hijo?

Las investigadoras mantendrán todos los registros del estudio archivados en un lugar seguro. Todos los archivos electrónicos que contengan información personal serán protegidos por contraseña, en una computadora bloqueada. Sólo las investigadoras tendrán acceso a las contraseñas. No se compartirá ninguna información personal de su hijo/a. Al final de este estudio, las investigadoras podrán publicar sus resultados. La identidad de su hijo/a no será revelada en las publicaciones o presentaciones.

También debe saber que la Junta de Revisión Institucional (IRB) de UConn y la Oficina de Cumplimiento de Investigación puede inspeccionar los registros de estudio como parte de su programa de auditoría, la cual sólo se enfocara en los investigadores y no en las respuestas o la participación de su hijo/a. La IRB es un grupo de personas que examina los estudios de investigación para proteger los derechos y el bienestar de los participantes de la investigación.

¿Puede mi hijo/a abandonar el estudio y cuáles son los derechos míos y de mi hijo/a?

Su hijo/a no tiene que participar en el estudio si usted no lo desea. Si usted permite a su hijo/a formar parte del estudio, pero luego cambia de parecer, puede retirar a su hijo/a en cualquier momento. La maestro/a puede desistir del estudio también. No hay penalidades o consecuencias de ningún tipo si decide terminar la participación de su hijo/a. Se le informara de todos los resultados importantes durante el transcurso del estudio que puede afectar a su disposición para permitir que su hijo/a continúe el estudio.

\section{¿A quién puedo contactar si tengo preguntas sobre el estudio?}

Tome todo el tiempo necesario antes de decidir. Contestaremos con todo placer a cualquier pregunta que tenga sobre el estudio. Si tiene alguna pregunta sobre este estudio, o si tiene un problema relacionado con la investigación, puede entrar en contacto con la investigadora principal, Dr. Melissa Bray (860-486-0167) o la investigadora estudiantil, Jennifer Ortiz (203-988-3613). Si tiene cualquier pregunta referente a los derechos de su hijo/a como un participante de una investigación, usted puede llamar directamente a la Universidad de Connecticut Junta de Revisión Institucional (IRB) en 860-486-8802. 
Autorización Parental para Participar en un Estudio de Investigación

\section{Wniversity of Connecticut}

\section{Investigadora Principal: Melissa Bray, $\mathrm{PhD}$}

Investigadora Estudiantil: Jennifer Ortiz, MA

Título del Estudio: El Juego de Buena Conducta como una estrategia de comportamiento para estudiantes de inglés.

\section{Documentación de Permiso:}

Yo he leído este formulario y he decidido conceder permiso a mi hijo/a para participar en el estudio descrito anteriormente. Sus propósitos generales, los detalles de su participación y los posibles riesgos e inconveniencias han sido explicados a mi satisfacción. Entiendo que puedo retirar a mi hijo en cualquier momento. Mi firma también indica que he recibido una copia de este formulario de permiso parental.

Usted puede guardar el formulario, y sólo devolver esta página de firma a su maestro/a antes de

Nombre del estudiante:

Firma:

Nombre:

Fecha:

Relación al estudiante:

Firma de persona que

Nombre:

Fecha

obtiene consentimiento 
APPENDIX C

Assent Script 


\section{Dear [student],}

Your teacher recommended you for a small group. I will organize this group, and we will focus on friendship, school rules, and playing in a safe and appropriate manner. I would like to use a new program called the Good Behavior Game (GBG). I hope the program can help students participate cooperatively in our group. I need your permission because GBG has not been used with students who speak both English and Spanish like you, and I would like to watch your progress for a research study. If you participate, you will not have to do anything differently. I will remind the group about our rules, I will observe you, and you may earn prizes. Do you have any questions about the program or the research project?

\section{Estimado/a [estudiante]}

Tu maestro/a se recomendó para un grupo pequeño. Yo voy a organizar este grupo, y centramos en la amistad, las reglas de la escuela, y jugando en una manera segura y apropiada. Me gustaría usar un nuevo programa con este grupo que se llama el Juego de Buena Conducta (JBC). Espero que el programa puede ayudar a los estudiantes a participar cooperativamente en nuestro grupo. Necesito tu permiso porque el JBC no fue utilizado con estudiantes quien habla ambos el español y el inglés, como tu. Me gustaría observar tu progreso para una investigación de recurso. Si participas, no tienes que hacer nada diferente. Voy a recordar el grupo sobre nuestras reglas, te observaré, y puedes ganar premios. Tienes preguntas sobre el programa o el proyecto de investigación? 
APPENDIX D

Baseline Implementation Checklist and Data Collection Form 


\section{--Miss Ortiz' Group--}

Student:

Date:

BASELINE Session No.: $1 \quad 1 \quad 2 \quad 3$

$0 \quad$ 1. Turn timer on for 20 minutes

- 2. Record a check below for target student's disruptive behavior

○ 3. End recording when timer sounds

\begin{tabular}{|c|l|}
\hline & Record frequency as a tally mark: \\
\hline Interrupting & \\
\hline Out of Seat & \\
\hline
\end{tabular}

Notes: 


\section{APPENDIX E}

Intervention Implementation Checklist and Data Collection Form 


\section{--Miss Ortiz' Group--}

Student:

Date:

GBG Session No.: $\quad 1 \quad 2 \quad 3 \quad 4$

\section{5}

- 1. Turn timer on for 20 minutes

- 2. Announce start: "Today we are playing the Good Behavior Game."

$0 \quad 3$. Review Rules: "If we leave our seat, or if we interrupt each other, we earn a check. If we stay below checks today, we can earn a reward!"

$0 \quad 4$. Identify child and specific problem behavior in a neutral tone of voice

- 5. Record a check mark on white board

○ 6. Record a check below for target student's disruptive behavior

○ 7. Periodically praise students for good behavior

- 8. End recording when timer sounds

- 9. Review white board and announce if students earned a reward.

\begin{tabular}{|l|l|}
\hline & Record frequency as a tally mark: \\
\hline Interrupting & \\
\hline Out of Seat & \\
\hline
\end{tabular}

Notes: 